\title{
Kestabilan Inokulan Azotobacter selama Penyimpanan pada Dua Suhu
}

\author{
Reginawanti Hindersah*) dan Rija Sudirja \\ Fakultas Pertanian, Universitas Padjadjaran, Bandung 40600 \\ Diterima 30-12-2009 Disetujui 12-03-2011
}

\begin{abstract}
Azotobacter might be used as biological agents in bioremediation of heavy metal-contaminated soil since this rhizobacteria produce exopolysachharides (EPS) that mobilize soil heavy metals, and phytohormones that regulate root growth. So that heavy metal uptake by the roots could be increased. The objective of this research was to verify the stability of EPS and phytohormones in Azotobacter liquid inoculants during four months in different temperature storage. Liquid inoculants has been produced in EPS-induced media and stored in $20^{\circ} \mathrm{C}$ and room temperature $\left(24-27^{\circ} \mathrm{C}\right)$ during four months. The results showed that the better temperature storage was room temperature instead of $20^{\circ} \mathrm{C}$ since $\mathrm{pH}$, total $\mathrm{N}$, and EPS and phytohormones content was relatively stable during storage.
\end{abstract}

Keywords: azotobacter, exopolysaccharide, inoculant quality, phytohormones, temperature storage

\section{PENDAHULUAN}

Di lahan pertanian, kontaminan logam berat dapat berasal dari pupuk organik dan pupuk anorganik terutama pupuk fosfat berbahan dasar batuan fosfat (Alloway 1995; Chien et al. 2003; Chen et al. 2008). Bioremediasi tanah terkontaminasi logam berat merupakan metode yang relatif mudah dan efektif terutama jika dilakukan bersamaan dengan fitoremediasi oleh tanaman akumulator logam berat. Azotobacter adalah rizobakteri yang berpotensi dimanfaatkan sebagai agen hayati untuk remediasi logam berat. Selama ini Azotobacter telah digunakan sebagai pupuk hayati karena memfiksasi nitrogen dan memproduksi fitohormon.

Azotobacter juga menghasilkan eksopolisakarida (EPS) yang telah diketahui dapat membentuk kompleks dengan logam berat (LB) sehingga terbentuk kompleks EPS-LB yang stabil dan mobil (Chen et al. 1995). Dengan demikian, mobilitas logam berat di dalam tanah akan meningkat dan selanjutnya serapannya oleh akar tanaman meningkat pula. Fitohormon sitokinin dan giberelin yang dihasilkan Azotobacter berperan penting dalam remediasi logam berat. Konstribusi Azotobacter untuk meningkatkan perakaran melalui produksi fitohormon telah diperlihatkan pada tanaman jagung (Hindersah et al. 2003). Perakaran yang intensif akan meningkatkan zone eksplorasi tanah sehingga serapan suatu unsur hara di dalam tanah akan meningkat.

Untuk mengoptimalkan peran Azotobacter dalam bioremediasi logam berat perlu dilakukan optimasi produksi inokulan sehingga inokulan yang dihasilkan menghasilkan
EPS dan fitohormon. Kestabilan kadar EPS dan fitohormon di dalam inokulan cair dapat berubah selama penyimpanan. Kondisi penyimpanan terutama suhu akan berperan penting dalam kestabilan kualitas tersebut karena Azotobacter adalah bakteri mesofil pertumbuhan sel dan metabolisme optimal pada suhu $30-35^{\circ} \mathrm{C}$ (Holt et al. 1994). Dengan demikian, seharusnya inokulan disimpan pada suhu di bawah suhu optimum tersebut untuk menurunkan aktivitas bakteri. Penelitian ini dilakukan untuk mendapatkan informasi tentang kestabilan kadar EPS dan fitohormon selama empat bulan penyimpanan pada suhu $20^{\circ} \mathrm{C}$ dan suhu ruang.

\section{BAHANDANMETODE}

Inokulan Azotobacter sp LKM6 diproduksi pada fermentor kapasitas 21 pada suhu $30^{\circ} \mathrm{C}$ selama 48 jam. Media produksi adalah media cair Vermani dengan $\mathrm{N}$ (Vermani et al. 1997), yang dapat menginduksi produksi eksopolisakarida. Sebanyak $10 \%$ kultur cair biakan murni Azotobacter sp. LKM6 dengan kepadatan sel $10^{9} \mathrm{cfu} \mathrm{ml}^{-1}$ diinokulasikan ke dalam 11 media Vermani cair di dalam fermentor steril. Selanjutnya $250 \mathrm{ml}$ inokulan dipindahkan ke dalam wadah plastik komersial putih tidak transparan yang disimpan pada suhu $20^{\circ} \mathrm{C}$ dan suhu kamar selama 4 bulan.

Pengujian stabilitas dilakukan melalui suatu percobaan laboratorium yang dirancang dalam Rancangan Acak Lengkap dengan empat ulangan. Faktor yang diuji adalah suhu penyimpanan yaitu $20^{\circ} \mathrm{C}$ dan suhu kamar $\left(24-27^{\circ} \mathrm{C}\right)$.

\footnotetext{
*Telp: +62811221834

Email: reginawanti@yahoo com
} 
Stabilitas inokulan selama empat bulan penyimpanan ditentukan berdasarkan perubahan 1) konsentrasi nitrogen dengan metode Kjeldahl, 2) pH dengan metode potensiometri, 3) populasi sel dengan metode langsung menggunakan bilik hitung, 4) konsentrasi EPS, dan 5) konsentrasi fitohormon sitokinin dan giberelin di dalam inokulan. Variabel di atas ditentukan setiap bulan dari lima sampel. Data akan dianalisis dengan Analisis Ragam dan dilanjutkan dengan Uji Beda Nyata Terkecil pada taraf 5\% menggunakan SigmaStat ver. 2.01.

Analisis pH dan $\mathbf{N}$ total. Pengukuran $\mathrm{pH}$ dilakukan dengan mencampur kultur dengan $\mathrm{H}_{2} \mathrm{O}$ (1:2,5; v:v) dan dibiarkan selama 15 menit, kemudian $\mathrm{pH}$ diukur dengan $\mathrm{pH}$ meter yang menggunakan elektroda gelas (Van Reeuwijk 1992).

$\mathrm{N}$ total ditentukan dengan metoda Kjeldahl (Van Reuwijk 1992). Nitrogen di dalam kultur dimineralisasi dalam bentuk amoniak pada kondisi asam $\left(\mathrm{H}_{2} \mathrm{SO}_{4}\right)$ dengan bantuan katalisator. Total nitrogen ditentukan melalui destilasi. Amoniak dibebaskan dengan penambahan $\mathrm{NaOH}$ menjadi amonium sulfat. Amoniak dititrasi dengan asam klorida dengan bantuan indikator untuk menentukan kadar N.

Analisis Eksopolisakarida. Penentuan konsentrasi eksopolisakarida di dalam kultur cair diawali dengan mensentrifugasi $20 \mathrm{ml}$ kultur bakteri pada $7000 \mathrm{rpm}$ (Centrifuge medium Hitachi Himac CF 7D2) pada $4^{\circ} \mathrm{C}$ selama 20 menit. Sebanyak $10 \mathrm{ml}$ supernatan ditambah dengan $20 \mathrm{ml}$ aseton teknis dingin dan dibiarkan semalam pada suhu $4^{\circ} \mathrm{C}$ sebelum disentrifugasi $7000 \mathrm{rpm}$ pada $4^{\circ} \mathrm{C}$ selama 20 menit. Supernatan dibuang dan (eksopolisakarida) EPS di dasar tabung dipindahkan ke kertas Whatman no. 1 yang telah ditimbang setelah pemanasan $35^{\circ} \mathrm{C}$ selama 1 jam. Kertas berisi EPS dipanaskan $35^{\circ} \mathrm{C}$ selama 1 jam dan dimasukan ke dalam desikator selama 20 menit sebelum ditimbang. Berat EPS adalah berat kertas saring dengan EPS dikurangi berat kertas saring tanpa EPS.

Analisis Fitohormon . Analisis kuantitatif fitohormon di dalam inokulan cair dilakukan dengan cara mengekstraksi sitokinin tersebut dengan pelarut metanol. Sebanyak $50 \mathrm{ml}$ larutan hara ditambah dengan metanol (85:15), kemudian diblender pada kecepatan $2000 \mathrm{rpm}$ selama beberapa menit. Setelah itu, larutan disaring dengan kertas saring Whatman no. 40 dan diliofilisasi (Freeze-drying) sampai mencapai volume $50 \mathrm{ml}$. Sebanyak $1 \mathrm{ml}$ ekstrak dikromatografi kolom dengan menggunakan kolom kontinyu yang terdiri atas PVP (Polivinil Pirolidon), kolom Sepak $\mathrm{C}_{18}$ dan kolom penukar kation SCX dengan pengelusi metanol. Tinggi dan diameter kolom masing-masing $2 \mathrm{~cm}$ dan $1 \mathrm{~cm}$. Fraksi (1 ml) dikoleksi setelah 1 jam. Selanjutnya, $1 \mu$ fraksi di atas dianalisis dengan HPLC fasa terbalik dengan menggunakan kolom $\mu$ Bondapak $\mathrm{C}_{18} / 280 \mathrm{~nm}$, pelarut asetonitril (60:40) pada laju alir $1.0 \mathrm{ml} / \mathrm{menit}$ yang dioperasikan pada suhu kamar (Chen 1987). Adanya sitokinin dan giberelin deteksi dengan detektor UV-VIS Spektrofotometer pada panjang gelombang 254.

\section{HASIL DAN PEMBAHASAN}

Suhu rendah yang relatif konstan akan berpengaruh terhadap kerja enzim organisme mesofil seperti Azotobacter. Suhu penyimpanan $20 \pm 1^{\circ} \mathrm{C}$ di ruangan tertutup berpendingin ternyata tidak menyebabkan perbedaan $\mathrm{pH}$, kandungan $\mathrm{N}$ total dan kepadatan sel inokulan cair Azotobacter sp. LKM6. Demikian pula tidak ada perbedaan yang besar dari nilai konsentrasi EPS dan fitohormon selama 4 bulan penyimpanan

Kemasaman, konsentrasi $\mathbf{N}$ dan kepadatan sel inokulan cair. Suhu penyimpanan tidak berpengaruh terhadap kemasaman, konsentrasi $\mathrm{N}$ dan kepadatan sel inokulan cair Azotobacter sp. LKM6 selama penyimpanan 3 bulan (Gambar 1) dan bahkan 4 bulan. Jika dibandingkan dengan pH inokulan cair sebelum inkubasi yaitu 5.9, maka di bulan pertama terjadi penurunan $\mathrm{pH}$ yang dapat disebabkan masih terbentuknya asam organik oleh Azotobacter. Menurut penelitian Kurniawati et al. (2006), Azotobacter sp UT1 yang diisolasi dari Andisols Ungaran menghasilkan asam-asam organik. Hindersah (2008), telah pula membuktikan bahwa selama masa inkubasi, Azotobacter sp. LKM6 menghasilkan asam organik seperti laktat, piruvat, manuronat, glukuronat dan galakturonat. Kemasaman inokulan menurun setelah penyimpanan dua bulan dan kembali menurun pada saat mencapai 3 bulan (Gambar 1a). Namun penurunan ini berhenti pada bulan ke 4. Peningkatan $\mathrm{pH}$ dapat disebabkan terbentukan $\mathrm{CO}_{2}$ hasil degradasi sempurna bahan organik oleh Azotobacter yang

Tabel 1 Kemasaman, $\mathrm{N}$ total, populasi bakteri, konsentrasi eksopolisakarida dan fitohormon inokulan Azotobacter sp. LKM6 setelah empat bulan penyimpanan pada suhu $20^{\circ} \mathrm{C}$ dan $25-27^{\circ} \mathrm{C}$

\begin{tabular}{lcc}
\hline \multirow{2}{*}{ Variabel } & \multicolumn{2}{c}{ Suhu penyimpanan $\left({ }^{0} \mathrm{C}\right)$} \\
\cline { 2 - 3 } & 20 & $25-27$ \\
\hline Keasaman & $6,38 \mathrm{a}$ & $6,87 \mathrm{a}$ \\
$\mathrm{N}$ total $(\%)$ & $0,18 \mathrm{a}$ & $0,19 \mathrm{a}$ \\
Populasi $\left(10^{8} \mathrm{sel} \mathrm{ml}^{-1}\right)$ & $8,67 \mathrm{a}$ & $7,24 \mathrm{a}$ \\
EPS $\left(\mathrm{g} \mathrm{l}^{-1}\right)$ & $2,10 \mathrm{a}$ & $2,63 \mathrm{a}$ \\
Sitokinin $\left(\mathrm{mg} \mathrm{l}^{-1}\right)$ & $42,00 \mathrm{a}$ & $59,32 \mathrm{~b}$ \\
Giberelin $\left(\mathrm{mg} \mathrm{l}^{-1}\right)$ & $17,80 \mathrm{a}$ & $17,01 \mathrm{a}$ \\
\hline
\end{tabular}

Keterangan: Angka yang diikuti dengan huruf yang sama di dalam satu baris tidak berbeda nyata menurut Uji Beda Nyata Terkecil pada taraf $5 \%$ 
heterotrof (Holt et al. 1994). Penyimpanan dalam botol tidak tembus cahaya dengan volume 11 (diisi inokulan $750 \mathrm{ml}$ ) selama 3 bulan berikutnya kelihatannya menjamin suplai oksigen untuk bakteri. Dengan demikian, degradasi bahan organik tidak parsial dan tidak terjadi fermentasi yang menghasilkan asam.

Konsentrasi $\mathrm{N}$ total di kultur ini tidak dipengaruhi oleh suhu. Selain itu, waktu penyimpanan tidak banyak mengubah nilai N. Inokulan diproduksi pada kondisi dengan nitrogen sehingga Azotobacter tidak memfiksasi N (Abbass \& Okon 1993). Di dalam inokulan, $\mathrm{N}$ berasal dari sisa $\mathrm{HNO}_{3}$ di dalam media dan dari sel bakteri. Namun pada penelitian

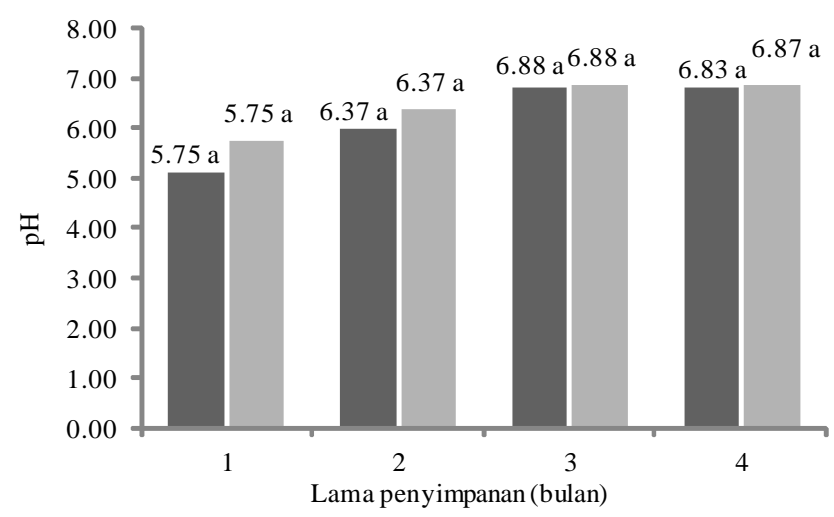

$\mathbf{A}$

- Suhu $20 \mathrm{C} \quad$ Suhu 25-27 C
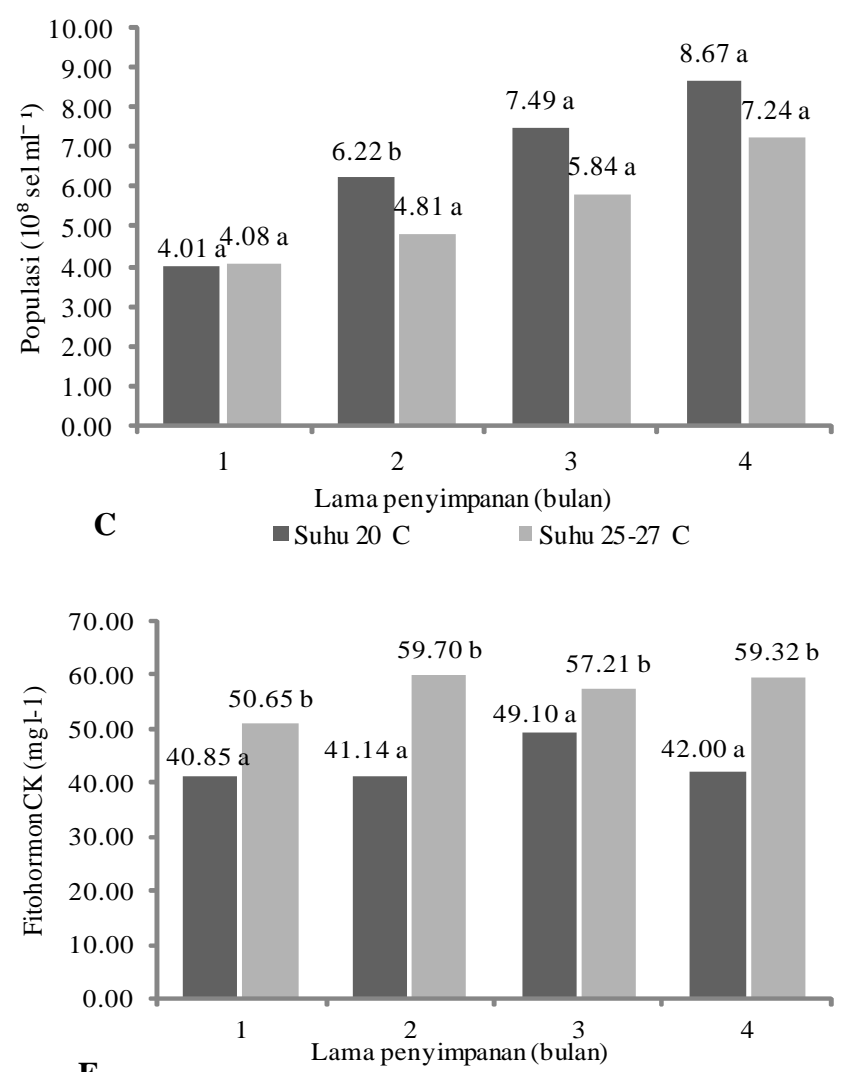

$\mathbf{E}$

$$
\text { - Suhu } 20 \mathrm{C} \quad \square \text { Suhu 25-27 C }
$$

ini, kepadatan sel sedikit menurun pada bulan pertama. Pada bulan selanjutnya konsentrasi $\mathrm{N}$ meningkat kembali dan relatif konstan memasuki bulan ke 3 dan 4 (Gambar 1b). Fenomena ini menunjukkan bahwa nutrisi di dalam media Vermani masih cukup untuk metabolisme bakteri.

\section{Konsentrasi Eksopolisakarida dan Fitohormon} inokulan cair. Selama pengamatan 4 bulan, suhu penyimpanan memberikan pengaruh yang variatif terhadap konsentrasi EPS dan fitohormon. Selama disimpan satu bulan, konsentrasi EPS terlihat menurun jika dibandingkan dengan sesaat setelah inokulan diproduksi. Sebelum disimpan inokulan mengandung $2.61 \mathrm{~g} \mathrm{l}^{-1}$ EPS. Namun
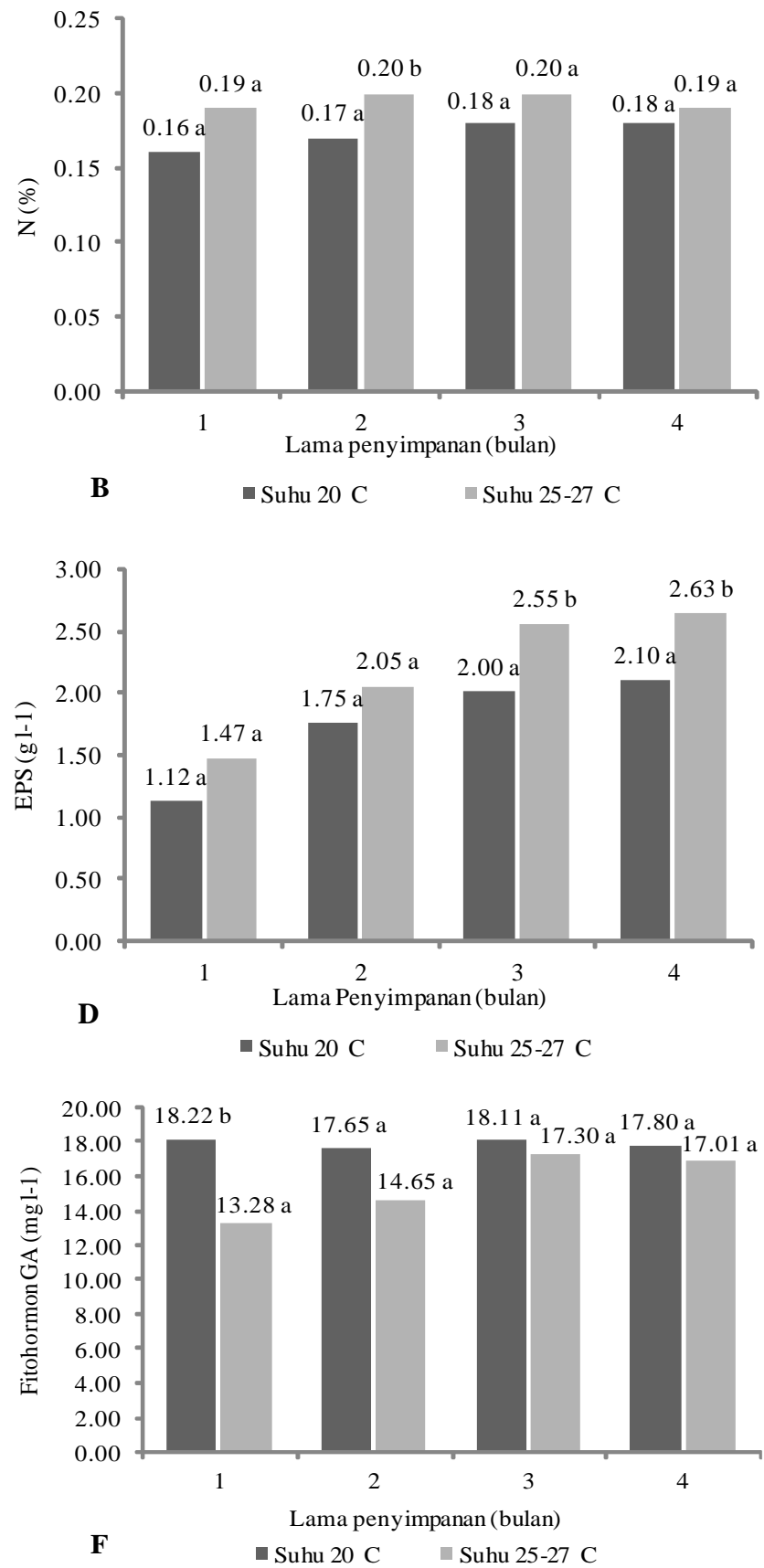

Gambar 1 Pengaruh suhu dan lama penyimpanan inokulan Azotobacter sp. LKM6 terhadap pH, N total, populasi bakteri, konsentrasi Keterangan : Angka yang diikuti dengan huruf yang sama tidak berbeda nyata menurut Uji Beda Nyata Terkecil pada taraf 5\% eksopolisakarida, fitohormon sitokinin (CK) dan fitohormon giberelin (GA) 
penyimpanan sampai 3 bulan meningkatkan konsentrasi EPS tetapi pada bulan ke empat, konsentrasi EPS tidak berubah banyak (Gambar 1c). Fenomena yang menarik adalah pada inokulan yang disimpan di suhu kamar, konsentrasi EPS di bulan ke 2-4 lebih besar daripada di suhu $20^{\circ} \mathrm{C}$.

Peningkatan konsentrasi EPS di dalam kultur cair dapat disebabkan oleh jumlah EPS yang diproduksi per satu satuan sel Azotobacter sp. LKM6 seperti yang telah dibuktikan oleh Hindersah (2008). Pada penelitian ini peningkatan suhu menginduksi pembentukan EPS.

Konsentrasi fitohormon dipengaruhi oleh lama penyimpanan (Gambar 1d dan 1f). Sebelum inkubasi, konsentrasi sitokinin dan giberelin adalah masing-masing 60,34 dan 20,07 $\mathrm{mg} \mathrm{l}^{-1}$. Secara umum, kandungan fitohormon di dalam inokulan menurun selama penyimpanan. Namun penurunan ini tidak terlalu banyak mengingat ada kemungkinan fitohormon didegradasi selama penyimpanan atau digunakan mikroba untuk proliferasi.

Pengaruh yang nyata terhadap fitohormon adalah suhu penyimpanan. Suhu kamar lebih menjaga konsentrasi fitohormon sitokinin tetapi tidak untuk giberelin. Di bulan pertama peyimpanan di suhu $20^{\circ} \mathrm{C}$ menurunkan konsentrasi sitokinin yang lebih besar dibandingkan dengan penurunan di inokulan yang disimpan di suhu kamar. Gambar 1e dan $1 \mathrm{f}$ terlihat bahwa konsentrasi sitokinin maupun giberelin di akhir inkubasi relatif konstan di dalam inokulan yang disimpan pada suhu kamar.

Hasil penelitian ini memperlihatkan bahwa penyimpanan pada suhu rendah berpotensi menurunkan kualitas inokulan cair Azotobacter yang dibuat untuk tujuan produksi EPS dan Fitohormon untuk bioremediasi yang disertai fitoremediasi tanah terkontaminasi logam berat. Dalam bioremediasi logam berat, EPS berperan dalam pembentukan kompleks EPS-logam berat yang memobilisasi logam berat sehingga dapat diserap oleh tanaman akumulator (Hindersah et al. 2007). Di lain pihak, fitohormon, terutama sitokinin, berperan penting dalam pembelahan dan pembesaran sel (Coenen \& Lomax 1998). Keberadaan sitokinin di dalam inokulan memberikan asupan sitokinin untuk tanaman jika inokulan diberikan melalui perakaran. Fitohormon ini diharapkan meningkatkan pertumbuhan akar tanaman remediasi. Peningkatan biomassa akar akan meningkatkan zone eksplorasi akar sehingga akar menyerap lebih banyak logam berat dan mentransportasikannya ke tajuk.

Pengujian penyimpanan ini membuktikan bahwa inokulan ini tidak perlu disimpan di suhu rendah, cukup di suhu ruang. Namun mungkin yang terpenting adalah bahwa pada penelitian ini, ruangan dan tempat penyimpanan inokulan Azotobacter sp. LKM6 tidak terpapar sinar matahari langsung.

\section{SIMPULAN}

Penyimpanan inokulan terbaik adalah pada suhu kamar daripada suhu $20^{\circ} \mathrm{C}$ karena lebih menjamin kestabilan $\mathrm{pH}, \mathrm{N}$ total, konsentrasi eksopolisakarida dan fitohormon, selama empat bulan penyimpanan.

\section{UCAPANTERIMAKASIH}

Kami berterimakasih kepada Kepala Balai Pengawasan dan Sertifikasi Benih Tanaman Pangan dan Hortikultura Pemda Jawa Barat di Bandung untuk dapat menggunakan fasilitas sehingga penelitian ini dapat berlangsung.

\section{DAFTAR PUSTAKA}

Abbass, Z. \& Okon, Y. 1993. Plant Growth Promotion by Azotobacter paspali in The Rhizosphere. Soil Biol. Biochem 8: $1075-1083$.

Alloway, B.J. 1995. Cadmium. Di dalam: Alloway, B.J (ed). Heavy Metals in Soils. Blackie Academic \& Professional. Glasgow.

Coenen, C. \& Lomax, T.L. 1998. The Diageotropica Gene Differentially Affects Auxin and Cytokinin Responses Throughout Development in Tomato. Plant Physiol 117: 6372.

Chen, C-M. 1987. Characterization of Cytokinins and Related Compounds by HPLC. Di dalam: Linskens, H.F. and J.F. Jackson (ed.). High Performance Liquid Chromatography in Plant Sciences. Springer-Verlag. Berlin.

Chen, J-H., Czajka, D.R., Lion, L.W., Shuler, M.L. \& Ghiorse, W.C. 1995. Trace metal mobilization in soil by bacterial polymers. Environ. Health Perspect 103: 53-58.

Chen, W., Krage, N., Wu, L., Pan, G., Khosrivafard, M. \& Chang, A.C. 2008. Arsenic, cadmium, and lead in california cropland soils: role of phosphate and micronutrient fertilizers. J. Environ Qual 37: 689-95.

Chien, S.H., Carmona, G., Prochnow, L.L. \& Austin, E.R. 2003. Cadmium avalability from granulated and bulk-blended phosphate-potassium fertilizers. J. Environ. Qual 32: 19111914.

Hindersah, R, Arief, D.H., Sumarni, Y. \& Totowarsa. 2003. Produksi hormon sitokinin oleh Azotobacter. Prosiding Kongres dan Seminar Nasional HITI. Padang Juli 2003. 549-555.

Hindersah, R. 2008. Transportasi Kadmium Dari Tanah Ke Pupus Tanaman Selada (Lactuca Sativa) Oleh Eksopolisakarida Azotobacter Sp. Disertasi. Universitas Padjadjaran. Bandung.

Holt, J.G., Krieg, N.R., Shaley, J.T. \& William, S.T. 1994. Bergey's Manual of Determinative Bacteriology. William and Wilkins. Baltimore.

Kurniawati, F., Hindersah, R. \& Joy, B. 2006. Pengaruh aplikasi kadmium (Cd), inokulan dan eksopolisakarida Azotobacter sp UT1 terhadap Cd tanah, dan akumulasi Cd pada tajuk bibit selada (Lactuca sativa) . J. Pertanian Tropika. 9: 52-59.

Van Reeuwijk, L.P. 1992. Procedure for Soil Analysis. Fourth Edition. ISRIC. Wageningen. The Netherland.

Vermani, M.V., Kelkarand, S.M. \& Kamat, M.Y. 1997. Studies in polysaccharide production and growth of Azotobacter vinelandii MTCC 2459, a plant rhizosphere isolate. Lett. Appl. Microbiol 24: 379383. 